\title{
Ethanol extract of Antrodia camphorata inhibits proliferation of HCT-8 human colorectal cancer cells by arresting cell cycle progression and inducing apoptosis
}

\author{
GONG WANG $^{1}$, YUN WAN ${ }^{2}$, JINYAN ZHAO ${ }^{2}$ and ZHENFENG HONG ${ }^{2}$ \\ ${ }^{1}$ Fujian Academy of Traditional Chinese Medicine, Minhou, Fuzhou, Fujian 350104; ${ }^{2}$ Academy of Integrative Medicine, \\ Fujian University of Traditional Chinese Medicine, Minhou, Fuzhou, Fujian 350122, P.R. China
}

Received April 9, 2016; Accepted March 13, 2017

DOI: $10.3892 / \mathrm{mmr} .2017 .7207$

\begin{abstract}
Antrodia camphorata (AC) is well known in Taiwan as a traditional Chinese medicine, with a long history of use in treating cancer and inflammation. Previous studies have revealed that $\mathrm{AC}$ exhibits anticancer effects in various cancer cell lines. However, the inhibitory influence of AC on colorectal cancer (CRC) cell growth and survival remains unknown. The present study investigated the effects of $\mathrm{AC}$ on the proliferation, survival, and cell cycle- and apoptosis-associated gene and protein expression in the HCT- 8 human CRC cell line in vitro. The antitumor activity of AC against $\mathrm{HCT}-8$ cells was assessed using cell viability and colony formation assays. Cell cycle distribution was analyzed by flow cytometry. Cell apoptosis and morphological alterations were assessed by Hoechst 33258 staining and microscopy. The mRNA expression of cell cycle- and apoptosis-associated genes was determined by reverse transcription-quantitative polymerase chain reaction, and protein expression levels of B-cell lymphoma 2 (Bcl-2), Bcl-2 X associated protein (Bax) cyclin D1, cyclin dependent kinase 4 (CDK4) and MYC proto-oncogene bHLH transcription factor (c-Myc) were determined by western blotting. Treatment of HCT-8 cells with various concentrations of $\mathrm{AC}(0.4-1.2 \mathrm{mg} / \mathrm{ml})$ resulted in dose- and time-dependent reductions in cell viability. HCT- 8 cell cycle was arrested in the $\mathrm{G} 0 / \mathrm{G} 1$ phase or $\mathrm{G} 0 / \mathrm{G} 1$ and $\mathrm{G} 2 / \mathrm{M}$ phases following $\mathrm{AC}$ treatment, compared with untreated cells. Furthermore, AC markedly inhibited HCT-8 cell growth with induction of apoptotic alterations and inhibition of proliferation. AC treatment induced HCT-8 cell apoptosis, upregulated expression
\end{abstract}

Correspondence to: Professor Zhenfeng Hong, Academy of Integrative Medicine, Fujian University of Traditional Chinese Medicine, 1 Qiuyang Road, Shangjie, Minhou, Fuzhou, Fujian 350122, P.R. China

E-mail: zfhong1953@163.com

Key words: Antrodia camphorata, colorectal cancer, viability, proliferation, apoptosis of the apoptosis gene Bax, and downregulated Bcl-2, cMyc, cyclin D1 and CDK4 protein expression levels. The present data demonstrated that $\mathrm{AC}$ exhibited antiproliferative and growth inhibition effects on HCT-8 cells via induction of apoptosis and blocking of cell cycle progression, thus suggesting that it may have anticancer properties valuable for potential future therapeutic application for the treatment of CRC.

\section{Introduction}

Colorectal cancer (CRC) is the fourth most common cause of cancer mortality with $\sim 9.4 \%$ of cancer cases worldwide, irrespective of gender, and an increasing CRC incidence in Asia (1-3). Cancer prevention is the most cost-effective approach to cancer control; however, many cancers are only diagnosed at advanced stages when symptoms are present. As such, treatment to slow, stop or regress tumors is the most common approach. One of the most common antitumor therapeutic techniques is the inhibition of proliferation and induction of apoptosis in tumor cells $(4,5)$.

Despite improvements in surgical intervention and chemotherapy, the five-year survival rate for CRC patients remains poor (6). In recent years, a movement toward finding and developing improved therapeutic strategies and novel pharmaceutical compounds, particularly those with a natural origin, has been underway. A major focus has been on gathering information and understanding the mechanistic treatment properties and therapeutic potential for traditional medicines to reduce mortality in afflicted patients $(7,8)$.

Fungi, and specifically mushrooms, have long been used in traditional medicine to treat various diseases, including many types of cancers. Antrodia camphorata (AC) is a native fungus to Taiwan, and is rare and expensive as it grows only on the inner heartwood wall of the endemic evergreen Cinnamonum kanehirai and cannot be cultivated (9). AC has a long history of use as a traditional Chinese medicine for the treatment of numerous diseases and disorders in the past few decades, including liver diseases, food detoxification and various cardiovascular diseases $(10,11)$.

Previous studies have illustrated that AC exhibits a broad spectrum of antitumor activities, including apoptotic, antioxidative, and anti-inflammatory effects on human hepatocellular 
carcinomas and leukocytes (12-15). In addition, AC has been reported to induce apoptosis via death receptor-mediated and mitochondrial apoptotic signaling pathways, in hepatocellular carcinoma cells $(16,17)$.

Despite these findings, no documented effects of AC in the treatment of colon cancers have been described thus far. To identify whether AC has therapeutic potential in CRC, the present study examined the AC extract effects on cell viability, proliferation and apoptosis in the widely used HCT-8 human CRC cell line. In addition, the underlying molecular mechanisms of AC influence on these cancer cells were investigated The present findings may provide an important step toward the application of AC extract in the clinic for therapeutic use in human CRC.

\section{Materials and methods}

Reagents and antibodies. Dimethyl sulfoxide (DMSO), phosphate-buffered saline (PBS), trypsin-EDTA, fetal bovine serum (FBS), Roswell Park Memorial Institute (RPMI)-1640 medium, and penicillin-streptomycin were purchased from Thermo Fisher Scientific, Inc. (Waltham, MA, USA). A cell cycle assay kit was purchased from Nanjing KeyGen Biotech Co., Ltd. (Nanjing, China). Mouse or rabbit monoclonal antibodies specific for cyclin dependent kinase 4 (CDK4; 2906S), cyclin D1 (2978), c-myc (9402S), B-cell lymphoma 2 (Bcl-2; 2876 S), Bcl-2 associated X protein (BAX; 2772S) and $\alpha$-actin (4967L) were purchased from Cell Signaling Technology, Inc. (Danvers, MA, USA). Bicinchoninic acid (BCA) protein assay and Enhanced Chemiluminescence (ECL) kits were obtained from Pierce; Thermo Fisher Scientific, Inc. All other chemicals used were of the highest grade commercially available.

Preparation of ethanol extracts from A. camphorate. A. camphorata used in this study was obtained from Well Shine Biotechnology Development Co., Ltd. (Taipei, Taiwan). For preparation of the extract, $500 \mathrm{~g}$ A. camphorata were extracted with $70 \%$ ethanol using a refluxing method and filtered (18). The AC extract stock solution was dissolved in DMSO to a final concentration of $500 \mathrm{mg} / \mathrm{ml}$ and stored at $-20^{\circ} \mathrm{C}$ until use. Prior to use, the stock was thawed and appropriate amounts of the AC stock solution were filter sterilized through $0.22-\mu \mathrm{m}$ disc filters. Control cultures received the carrier solvent (0.1\% DMSO).

Cell culture and AC treatment. The HCT-8 human CRC cell line was obtained from Nanjing KeyGen Biotech Co., Ltd. and maintained at $37^{\circ} \mathrm{C}$ in a humidified incubator at $5 \% \mathrm{CO}_{2}$. HCT- 8 cells undergoing exponential growth were routinely cultured in $25 \mathrm{~cm}^{2}$ plastic flasks containing $5 \mathrm{ml}$ RPMI-1640 medium supplemented with $10 \%$ (v/v) FBS and antibiotics (100 U/ml penicillin and $100 \mathrm{mg} / \mathrm{ml}$ streptomycin). For AC treatment experiments, cells were incubated with $0.4,0.8$ and $1.2 \mathrm{mg} / \mathrm{ml} \mathrm{AC}$, by diluting the stock with DMEM, for $24 \mathrm{~h}$. Control cells were cultured in medium containing an equal amount of DMSO. Cells were washed with $2 \mathrm{ml}$ PBS once and harvested with $0.25 \%$ trypsin. The cells were then centrifuged at $800 \mathrm{x} \mathrm{g}$ for $3 \mathrm{~min}$ at $25^{\circ} \mathrm{C}$, and the isolated cells were used in subsequent experiments.
MTT assay. Various concentrations ( $0,0.4,0.8$ and $1.2 \mathrm{mg} / \mathrm{ml}$ ) of AC were added to 96 -well plates seeded with $8 \times 10^{3}$ HCT- 8 cells/well. Following treatment for the times indicated, $10 \mu \mathrm{l}$ of MTT solution ( $5 \mathrm{mg} / \mathrm{ml}$ stock; Merck KGaA, Darmstadt, Germany) was added to each well and the plate was incubated at $37^{\circ} \mathrm{C}$ for $4 \mathrm{~h}$. Following removal of medium, $100 \mu \mathrm{l}$ DMSO was added to each well and the plate was gently shaken for $5 \mathrm{~min}$. Absorbance was then measured at a wavelength of $570 \mathrm{~nm}$ using an ELISA plate reader (Model ELX800; BioTek Instruments, Inc., Winooski, VT, USA). The percentage of viable cells was determined through comparison with untreated control cells. Each experiment was replicated 3-5 times and all data are represented as mean \pm standard deviation.

Colony formation assay. To assess the AC effect on cell colony formation, cells were seeded into a 6-well-plate at a density of $2 \times 10^{5}$ cells/well. After $24 \mathrm{~h}$, cells were exposed $0,0.4$ or $0.8 \mathrm{mg} / \mathrm{ml} \mathrm{AC}$ or drug-free medium for $24 \mathrm{~h}$. The drug-containing or drug-free media was then removed, cells were plated at a density of $1 \times 10^{3} /$ well into $60-\mathrm{mm}$ dishes, and cells were incubated for 10 days under standard culture conditions as described above. Formed colonies were fixed in $4 \%$ paraformaldehyde for $30 \mathrm{~min}$ at $25^{\circ} \mathrm{C}$ and stained with $0.01 \%$ crystal violet for $15 \mathrm{~min}$. Colony-forming efficiency was determined and cell survival was calculated by normalizing against control cell survival, from five random fields per well for three independent experiments.

Cell cycle assay. A flow cytometer was used for cell cycle analysis (FACSCalibur; BD Biosciences, San Jose, CA, USA). HCT-8 cells were cultured in 6-well culture plates at a density of $1.5 \times 10^{5}$ cells/well and treated with $0,0.4$ or $0.8 \mathrm{mg} / \mathrm{ml} \mathrm{AC}$ for $24 \mathrm{~h}$. Following trypsinization, floating and adherent cells were collected by centrifuged at $800 \mathrm{x} \mathrm{g}$ for $5 \mathrm{~min}$ at $25^{\circ} \mathrm{C}$, washed with ice-cold PBS and then incubated with $30 \mu \mathrm{g} / \mathrm{ml}$ propidium iodide and $100 \mu \mathrm{g} / \mathrm{ml} \mathrm{RNase}$ for $24 \mathrm{~h}$ in the dark at room temperature. Data acquisition and calculation of the percentage cells in the sub-G1, G0/G1, S, and G2/M phases of the cell cycle were performed using the accompanying flow cytometer software ModfitLT version 3.3.11 (CellQuest; BD Biosciences). Twenty thousand events per sample were counted and a minimum of three assessments were performed to assure each cell cycle distribution.

Hoechst 33258 nuclear staining. HCT- 8 cells were plated at low density $\left(1.5 \times 10^{5}\right.$ cells/well $)$ into a 6 -well plate and treated with $\mathrm{AC}$ for 24 or $48 \mathrm{~h}$. At the end of the experiment, cells were washed twice with PBS at room temperature and then fixed with ice-cold $4 \%$ paraformaldehyde for $10 \mathrm{~min}$. Fixed cells were then rinsed with PBS and stained with Giemsa $(0.75 \mathrm{mg} / \mathrm{ml})$ or Hoechst $33258(10 \mu \mathrm{g} / \mathrm{ml})$ for $15 \mathrm{~min}$. Finally, cells were washed with PBS and analyzed under a fluorescence microscope with a UV light filter.

RNA extraction and reverse transcription-quantitative polymerase chain reaction ( $R T-q P C R)$. Total RNA from treated HCT-8 cells was extracted using a phenol/chloroform method with RNAiso reagent (Takara Biotechnology Co., Ltd., Dalian, China). The absorbance ratio at 260/280 nm of all samples was 
Table I. List of primers used for quantitative polymerase chain reaction.

\begin{tabular}{ll} 
Gene & \multicolumn{1}{c}{ Primer sequence (5'-3') } \\
\hline GAPDH & F: CTGCCTTCTCTTGTGACA \\
& R: TGTAGACCATGTAGTTGAGG \\
Cyclin D1 & F: GCGTTGTACCTGTAGGACTC \\
& R: TAAGCGTGAGCCGTGTTC \\
CDK4 & F: TGTGGAGTGTTGGCTGTATC \\
& R: AGGCAGAGATTCGCTTGTG \\
c-Myc & F: CGGAAACGACGAGAACAGT \\
& R: AGACTCAGCCAAGGTTGTG \\
Bax & F: AGGATGCGTCCACCAAGAAGC \\
& R: TGGCAAAGTAGAAAAGGGCGA \\
Bcl-2 & F: TCGCCCTGTGGATGACTGAG \\
& R: CAGAGTCTTCAGAGACAGCCAGGA
\end{tabular}

CDK4, cyclin dependent kinase 4; c-Myc, MYC proto-oncogene bHLH transcription factor; Bax, B-cell lymphoma $2 \mathrm{X}$ associated protein; Bcl-2, B-cell lymphoma 2; F, forward; R, reverse.

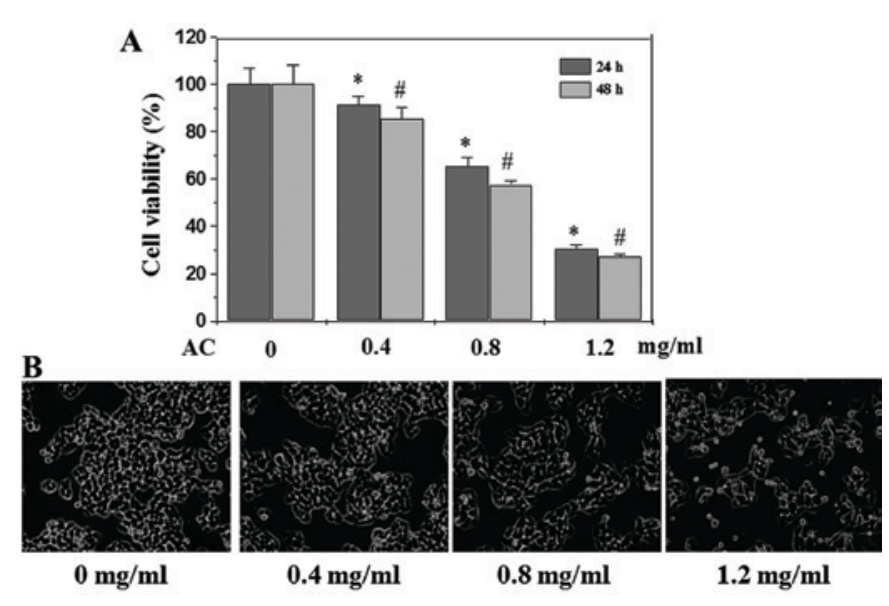

Figure 1. AC inhibits human colorectal cell viability. (A) HCT-8 cells were treated with $0,0.4,0.8$ or $1.2 \mathrm{mg} / \mathrm{ml} \mathrm{AC}$ for 24 and $48 \mathrm{~h}$. Following treatment, cell viability was measured by MTT assay. Data are expressed as the mean \pm standard deviation. ${ }^{~} \mathrm{P}<0.05$ and ${ }^{~} \mathrm{P}<0.05$ vs. $0 \mathrm{mg} / \mathrm{ml} \mathrm{AC}$, for 24 or $48 \mathrm{~h}$ respectively. (B) Morphological alterations of HCT-8 cells following treatment with AC. The photomicrographs were captured under a phase-contrast microscope (magnification, x200). AC, Antrodia camphorata ethanol extract.

determined using a NanoDrop ND-1000 spectrophotometer (Thermo Fisher Scientific, Inc.). Reverse transcription was performed using $1 \mu \mathrm{g}$ total RNA with the PrimeScript ${ }^{\mathrm{TM}}$ II First-Strand cDNA Synthesis kit (Takara Biotechnology Co., Ltd.), according to the manufacturer's protocol. qPCR was performed using SYBR Premix Ex Taq II (Takara Biotechnology Co., Ltd.) with an ABI 7500 Fast instrument according to the manufacturer's instructions. The reaction contained $10 \mu 1$ 2X SYBR Premix Ex Taq II, $0.8 \mu$ l forward primer $(10 \mu \mathrm{M}), 0.8 \mu 1$ reverse primer $(10 \mu \mathrm{M}), 0.4 \mu 1$ 50X ROX

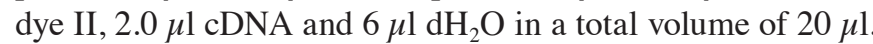
The qPCR reaction conditions were as follows: $30 \mathrm{sec}$ at $94^{\circ} \mathrm{C}$, followed by 40 cycles of $3 \mathrm{sec}$ at $94^{\circ} \mathrm{C}$ and $30 \mathrm{sec}$ at $60^{\circ} \mathrm{C}$. The primers used for qPCR are listed in Table I. Relative amount of target mRNA was calculated using the $2^{-\Delta \Delta C q}$ method (19).

Western blotting assay. Following treatment as indicated above, HCT-8 cells were harvested and incubated in ice-cold radioimmunoprecipitation assay buffer (Thermo Fisher Scientific, Inc.) with freshly added protease and phosphatase inhibitor cocktails (Roche Applied Science, Penzberg, Germany) on ice for $30 \mathrm{~min}$. The cells were scraped from the plate and the lysate was collected in a centrifuge tube and centrifuged at $12,000 \mathrm{x} \mathrm{g}$ for $20 \mathrm{~min}$ at $4^{\circ} \mathrm{C}$. The supernatant containing protein was collected, aliquoted, and stored at $-80^{\circ} \mathrm{C}$. The lysate protein concentrations were measured using a BCA protein assay kit, following the manufacturer's instructions. Total cell lysates $(50 \mu \mathrm{g})$ were separated by $10 \%$ SDS-PAGE and transferred to nitrocellulose membranes (EMD Millipore, Billerica, MA, USA). The membranes were blocked with $5 \%$ nonfat milk for $2 \mathrm{~h}$ at $25^{\circ} \mathrm{C}$ and incubated with primary antibodies (1:1,000 dilution) at $4^{\circ} \mathrm{C}$ overnight, followed by incubation with horseradish peroxidase-conjugated secondary antibodies (1:5,000 dilution) at room temperature. Membranes were subsequently visualized using an ECL detection kit.

Statistical analysis. All data are presented as means \pm standard deviation of three independent experiments and analyzed by one-way analysis of variance followed by Tukey's post hoc test, using SPSS Statistics version 20 software (IBM SPSS, Armonk, NY, USA). P $<0.05$ was considered to indicate a statistically significant difference.

\section{Results}

AC treatment downregulates cell growth and viability in HCT- 8 cells. To investigate the potential effects of AC treatment on proliferation of HCT- 8 cells, the cells were exposed to $0-1.2 \mathrm{mg} / \mathrm{ml} \mathrm{AC}$ for 24 and $48 \mathrm{~h}$. Fig. 1A demonstrates that $\mathrm{AC}$ inhibited cell proliferation in a dose- and time-dependent manner $(\mathrm{P}<0.05)$. When treated with $0.4,0.8$ and $1.2 \mathrm{mg} / \mathrm{ml}$ AC for 24 and $48 \mathrm{~h}, \mathrm{HCT}-8$ cell viabilities were 91 and $85 \%$, 65 and $57 \%$, and 31 and $27 \%$, respectively, compared with control untreated cells. Morphological changes in HCT-8 cells following AC treatment for $24 \mathrm{~h}$ were also evident (Fig. 1B). Based on phase-contrast inverse microscopy, the typical morphological apoptotic characteristics were observed post-treatment, including decreased cell number and an increase in apoptotic body formation, accompanied by an increased abundance of dead floating cells.

Effect of AC treatment on colony formation in HCT-8 cells. The ability of HCT- 8 cells to form colonies in the presence of $\mathrm{AC}$ was analyzed using a flat plate colony formation assay. The results illustrated in Fig. 2A suggest that AC effectively inhibited colony formation in a dose-dependent manner. Control untreated cells demonstrated increased colony formation ability compared with cells treated with AC ( $\mathrm{P}<0.05$; Fig. 2B). This evidence suggests that AC may have significantly affected HCT-8 cell proliferation.

AC inhibits cell cycle progression in HCT-8 cells. As AC appeared to inhibit HCT- 8 cell proliferation in vitro, the 

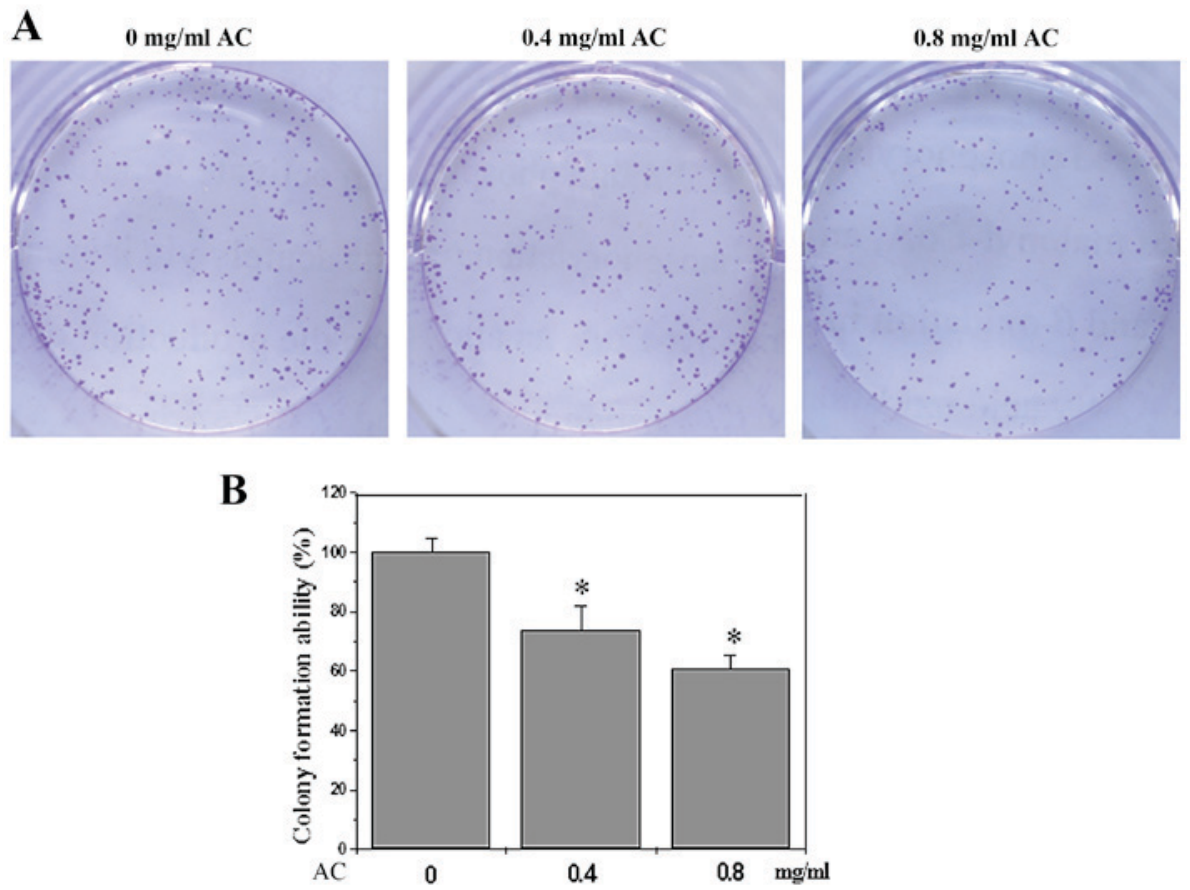

Figure 2. AC treatment inhibits HCT-8 cell colony formation. (A) HCT-8 cells were treated with $0,0.4 \mathrm{or} 0.8 \mathrm{mg} / \mathrm{ml}$ AC and allowed to form colonies in soft agar plates for 14 days. Representative plates are shown. (B) Quantification of the number of colonies per treatment group is presented as mean \pm standard deviation of three independent experiments. ${ }^{*} \mathrm{P}<0.05 \mathrm{vs} .0 \mathrm{mg} / \mathrm{ml}$ AC. AC, Antrodia camphorata ethanol extract.
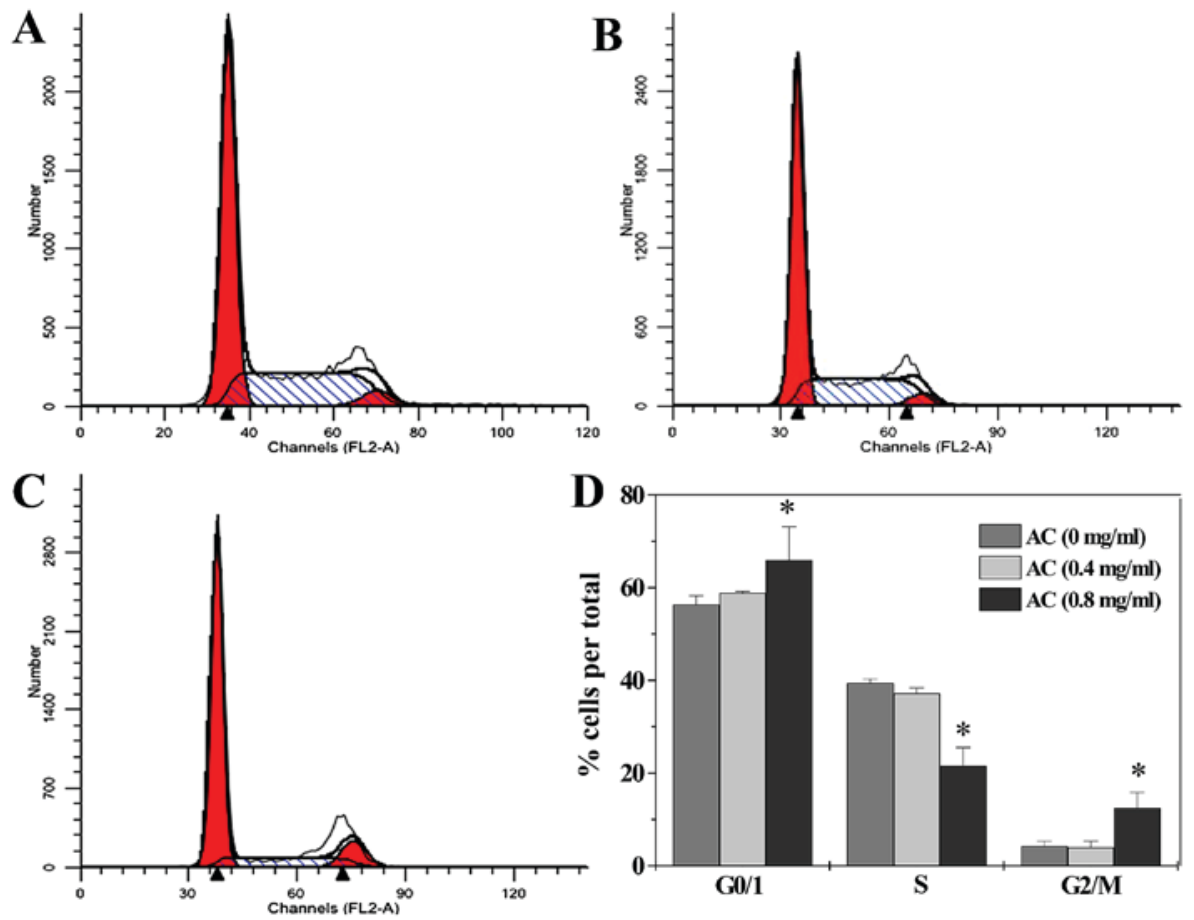

Figure 3. Flow cytometric analysis for HCT-8 cell phase distribution following AC treatment. HCT- 8 cells were treated with (A) 0 , (B) $0.4 \mathrm{or}$ (C) $0.8 \mathrm{mg} / \mathrm{ml}$ AC for $24 \mathrm{~h}$. Representative plots of cell cycle distribution per group are shown. (D) Quantification of the percentage of cells in the G0/G1, S and G2/M phases of the cell cycle. Data are presented as the mean \pm standard deviation of three independent experiments. ${ }^{*} \mathrm{P}<0.05 \mathrm{vs} .0 \mathrm{mg} / \mathrm{ml} \mathrm{AC}$. AC, Antrodia camphorata ethanol extract.

hypothesis that AC may influence cell cycle progression was tested via flow cytometry. Following treatment with $\mathrm{AC}$ for $24 \mathrm{~h}$, the percentage of cells in the $\mathrm{S}$ phase in the $0.8 \mathrm{mg} / \mathrm{ml}$ AC treatment group was significantly decreased compared with the control group (21.5 and 39.4\%, respectively; Fig. 3). In addition, the percentage of cells in the $\mathrm{G} 0 / 1$ phase was $56.4 \%$ in the control group and $66.0 \%$ in the $0.8 \mathrm{mg} / \mathrm{ml} \mathrm{AC}$ treatment group. AC treatment significantly increased the 


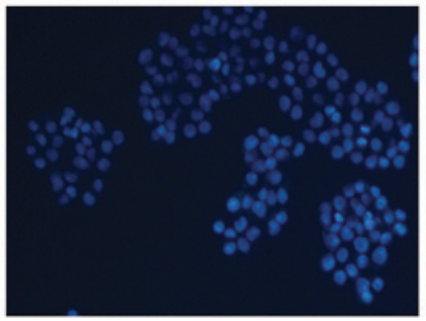

$0 \mathrm{mg} / \mathrm{ml}$

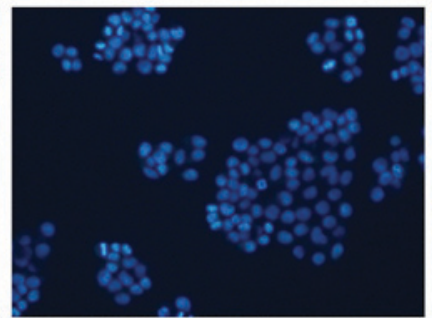

$0.4 \mathrm{mg} / \mathrm{ml}$

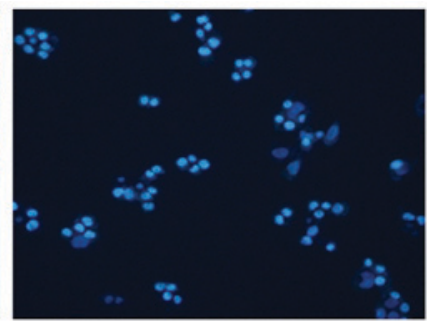

$0.8 \mathrm{mg} / \mathrm{ml}$

Figure 4. AC induces apoptotic nuclear morphological alterations in HCT-8 cells. Cells were treated with $0,0.4$ or 0.8 mg/ml AC for 24 h. Hoechst 33258 staining revealed AC-induced condensation of the nuclei. Original magnification, $\mathrm{x} 200$. AC, Antrodia camphorata ethanol extract.
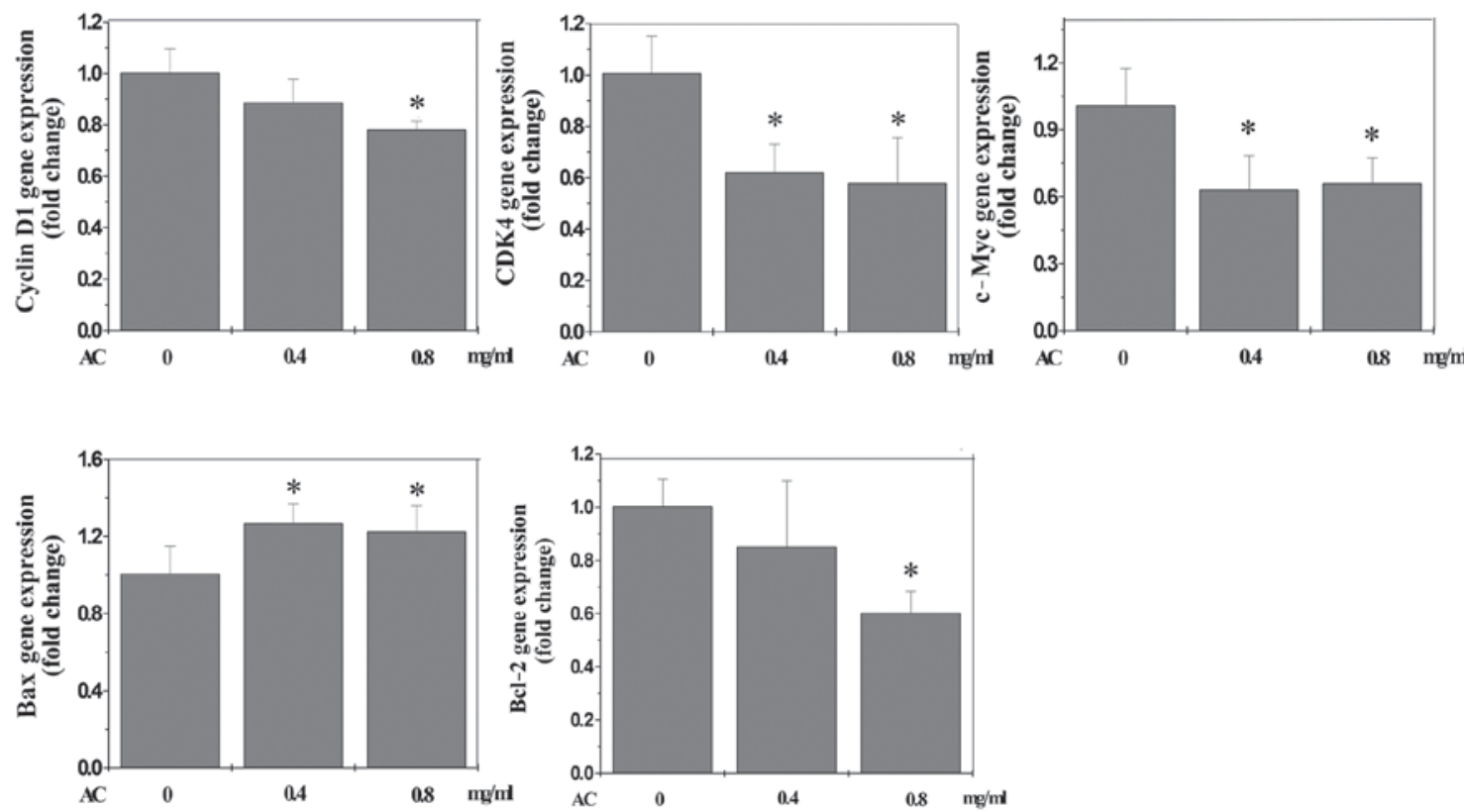

Figure 5. mRNA expression of cell cycle- and apoptosis-associated genes following AC treatment in HCT- 8 cells. Cells were treated with AC for 24 h, and total RNA was extracted. mRNA expression levels of cyclin D1, CDK4, c-Myc, Bax and Bcl-2was evaluated by reverse transcription-quantitative polymerase chain reaction. Data are presented as the mean \pm standard deviation of at least three independent experiments. ${ }^{*} \mathrm{P}<0.05 \mathrm{vs} .0 \mathrm{mg} / \mathrm{ml} \mathrm{AC}$. AC, Antrodia camphorata ethanol extract; CDK4, cyclin dependent kinase 4; c-Myc, MYC proto-oncogene bHLH transcription factor; Bax, B-cell lymphoma 2 X associated protein; Bcl-2, B-cell lymphoma 2 .

percentage of cells in the G0/G1 phase $(\mathrm{P}<0.05$; Fig. 3). These results suggested that $\mathrm{AC}$ arrested the cell cycle at the G0/G1 phase.

AC induces apoptosis-associated morphological alterations in HCT-8 cells. To visualize apoptotic body formation and nuclear morphological alterations characteristic of apoptosis, Hoechst 33258 staining was performed after $24 \mathrm{~h}$ treatment with 0.4 and $0.8 \mathrm{mg} / \mathrm{ml} \mathrm{AC}$ in HCT- 8 cells. Hoechst 33258 reagent is a membrane-permeable blue fluorescent dye that stains the cell nucleus and allows visualization of nuclear morphology. Control untreated cells exhibited characteristics of healthy cells with intact oval shape and uniform nuclei that stained less brightly with Hoechst (Fig. 4). However, cells treated with AC exhibited more brightly stained nuclei as treatment concentration increased (Fig. 4).

Effect of AC treatment on cell cycle-and apoptosis-associated $m R N A$ expression. Having demonstrated that AC affects colon cancer cell proliferation and apoptosis, the effect of AC treatment on associated gene expression was examined. The results demonstrated that the mRNA expression levels of cyclin D1, CDK4, cMyc and Bcl-2 were markedly downregulated in the AC treatment groups compared with the control group $(\mathrm{P}<0.05$; Fig. 5). In contrast, the mRNA expression levels of Bax were increased following treatment with $\mathrm{AC}$ for $24 \mathrm{~h}$ compared with the control group $(\mathrm{P}<0.05$; Fig. 5). These findings suggested that AC may inhibit proliferation and apoptosis of HCT-8 cells by regulating expression of cell division and apoptosis-associated genes.

Effect of AC treatment on cell cycle-and apoptosis-associated protein expression. To characterize the differential expression of Bax, cMyc, Bcl-2, cMyc, cyclin D1 and CDK4 proteins, western blot analysis was performed. As demonstrated in Fig. 6, incubation of HCT-8 cells with AC reduced Bcl-2 protein expression levels, a potent cell-death inhibitor, whereas it increased Bax protein levels, compared with untreated cells. 


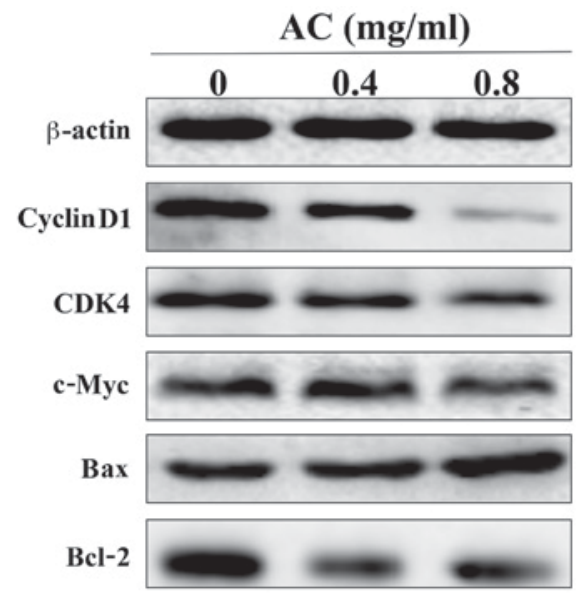

Figure 6. Expression of cell cycle- and apoptosis-associated proteins following AC treatment in HCT-8 cells. Representative western blot images of protein expression levels of cyclinD1, CDK4, cMyc, Bax and Bcl-2 following $24 \mathrm{~h} \mathrm{AC}$ treatment. $\beta$-actin served as a loading control. The results are representative of three independent experiments. AC, Antrodia camphorata ethanol extract; CDK4, cyclin dependent kinase 4; c-Myc, MYC proto-oncogene bHLH transcription factor; Bax, B-cell lymphoma $2 \mathrm{X}$ associated protein; Bcl-2, B-cell lymphoma 2.

These findings suggested that the AC-induced apoptosis may be associated with an AC-induced dysregulation of the Bcl-2/Bax ratio in HCT- 8 cells. In addition, the results demonstrated that $\mathrm{AC}$ treatment downregulated the protein expression levels of cyclin D1, CDK4 and cMyc in HCT-8 cells following AC treatment, compared with untreated cells (Fig. 6).

\section{Discussion}

$\mathrm{AC}$ is considered a physiologically beneficial fungus used in China for 2,000 years to improve health and enhance longevity. The mushrooms of this species are reported to possess potent antitumor, immune modulating, cardiovascular and hypercholesterolemia, antiviral, and antiparasitic activities (20-22). Notably, AC has been reported to exhibit cytotoxic effects against various cancer types, and therefore may have potential value for translational research in $\mathrm{CRC}$. To provide additional valuable information for the efficacy of $\mathrm{AC}$ in clinical application, the present study examined the effect of AC ethanol extract on the growth and viability of CRC cells.

Assessing the extent of proliferation and apoptosis in cells and tissues provides important clues into the efficacy of potential anticancer therapies, and many chemotherapeutic agents are reported to exert antitumor effects by inhibiting proliferation and inducing apoptosis in cancer cells (23-25). The present results demonstrated that AC treatment inhibited cell growth in HCT-8 CRC cells, potentially via blocking cell cycle progression and inducing apoptotic cell death.

Cyclin D1, a recognized oncogene, affects the G1/S phase transition of the cell cycle (26). Overexpression of cyclin D1 causes dysregulation of the cell cycle and induces abnormal cell proliferation (27). Cell cycle progression involves a sequential activation of CDKs, including CDK4, which are associated with $\mathrm{G} 1 / \mathrm{S}$ phase cell cycle progression $(28,29)$. The findings from the present study demonstrated that CDK4 and cylinD1 expression was decreased in AC-treated HCT-8 cells compared with untreated cells, which provides evidence of the mechanism by which $\mathrm{AC}$ reduces cell division. In addition, c-myc is a key transcription factor involved in controlling proliferation, differentiation and apoptosis. It heterodimerizes with the abundant helix-loop-helix molecule, MYC associated factor X, and is important for normal cell proliferation (30). C-myc has been reported to regulate cell proliferation via inhibiting the transcription of cell cycle checkpoint genes and CDK inhibitors, and to promote cell cycle progression via tactivation of cyclin D1, D2, E1, A2, CDK4, cyclin dependent kinase inhibitor $1 \mathrm{~A}$, cell division cycle 25A, E2 transcription factor (E2F) 1 and E2F2 (31). In the present study, AC significantly downregulated the expression of c-myc, suggesting that AC may inhibit HCT-8 cell proliferation by regulating the expression of CDK4, cylinD1 and c-myc.

Apoptosis is an important cellular process during the cell cycle, which triggers characteristic morphological and biological alterations (32). Prior studies have demonstrated that $\mathrm{Bcl}-2$ and Bax proteins are important in regulating apoptotic cell death (33-35). Of the Bcl-2 family members, the Bcl-2/Bax protein ratio has been recognized as a key indicator for regulation of apoptosis. As demonstrated in the present study, AC treatment resulted in a reduction of $\mathrm{Bcl}-2$ and an increase in Bax protein expression levels. Therefore, AC may shift the Bcl-2/Bax ratio toward a pro-apoptotic effect in HCT-8 cells, which is a promising finding for potential translation of this compound toward human cancer treatment application.

In conclusion, the present findings demonstrated that $\mathrm{AC}$ inhibited growth and induced apoptosis in human CRC cells in vitro, via suppression of the cell cycle, suggesting that $\mathrm{AC}$ may be potentially useful as a therapeutic cytotoxic drug in CRC. Follow up studies are required to evaluate the efficacy of this drug in vivo in tumor-bearing animal models.

\section{Acknowledgements}

The present study was supported by Fujian Provincial Science and Technology Department of Foreign Cooperation Key Project (grant no. 2014I0011) of Fujian Province, and the development of strategic emerging industries [Minfa-modified high tech special (2013); grant no. 577]. The authors also thank Clarity Manuscript Consultants, LLC (Indianapolis, IN, USA) for editorial and language assistance.

\section{References}

1. Armaghany T, Wilson JD, Chu Q and Mills G: Genetic alterations in colorectal cancer. Gastrointest Cancer Res 5: 19-27, 2012.

2. Ferlay J, Shin HR, Bray F, Forman D, Mathers C and Parkin DM: GLOBOCAN 2008 v1.2, Cancer Incidence and Mortality Worldwide, IARC Cancer Base No. 10. International Agency for Research on Cancer, Lyon, France, 2010.

3. Ng SC and Wong SH: Colorectal cancer screening in Asia. Br Med Bull 105: 29-42, 2013.

4. Zhang H, Gajate C, Yu LP, Fang YX and Mollinedo F: Mitochondrial-derived ROS in edelfosine-induced apoptosis in yeasts and tumor cells. Acta Pharmacol Sin 28: 888-894, 2007.

5. Jiang YH, Jiang XL, Wang P and Hu XK: In vitro antioxidant activities of water-soluble polysaccharides extracted from Isaria farinosa B05. J Food Biochem 29: 323-335, 2005.

6. Van Cutsem E, Nordlinger B and Cervantes A; ESMO Guidelines Working Group: Advanced colorectal cancer: ESMO clinical practice guidelines for treatment. Ann Oncol 21 (Suppl 5): V93-V97, 2010. 
7. Liu YH, Li ML, Hsu MY, Pang YY, Chen IL, Chen CK, Tang SW, Lin HY and Lin JY: Effects of a Chinese herbal medicine, Guan-Jen-Huang (Aeginetia indica Linn.), on renal cancer cell growth and metastasis. Evid Based Complement Alternat Med 2012: 935860, 2012.

8. Wu SH, Ryvarden L and Chang TT: Antrodia camphorata ('niu-chang-chih'), new combination of a medicinal fungus in Taiwan. Bot Bull Acad Sin 38: 273-275, 1997.

9. Kim SK and Wijesekara I: Development and biological activities of marine-derived bioactive peptides: A review. J Funct Foods 2: $1-9,2010$.

10. Ao ZH, Xu ZH, Lu ZM, Xu HY, Zhang XM and Dou WF: Niuchangchih (Antrodia camphorata) and its potential in treating liver diseases. J Ethnopharmacol 121: 194-212, 2009.

11. Yang SS, Wang GJ, Wang SY, Lin YY, Kuo YH and Lee TH: New constituents with iNOS inhibitory activity from mycelium of Antrodia camphorata. Planta Med 75: 512-516, 2009.

12. Yang HL, Lin KY, Juan YC, Kumar KJ, Way TD, Shen PC, Chen SC and Hseu YC: The anti-cancer activity of Antrodia camphorata against human ovarian carcinoma (SKOV-3) cells via modulation of HER-2/neu signaling pathway. J Ethnopharmacol 148: 254-265, 2013.

13. Lee CI, Wu CC, Hsieh SL, Lee CL, Chang YP, Chang CC, Wang YZ and Wang JJ: Anticancer effects on human pancreatic cancer cells of triterpenoids, polysaccharides and 1,3- $\beta$-D-glucan derived from the fruiting body of Antrodia camphorata. Food Funct 5: 3224-3232, 2014.

14. Chiou JF, Wu AT, Wang WT, Kuo TH, Gelovani JG, Lin IH, Wu CH, Chiu WT and Deng WP: A preclinical evaluation of Antrodia camphorata alcohol extracts in the treatment of non-small cell lung cancer using non-invasive molecular imaging. Evid Based Complement Alternat Med 2011: 914561, 2011.

15. Peng CC, Chen KC, Peng RY, Su CH and Hsieh-Li HM: Human urinary bladder cancer T24 cells are susceptible to the Antrodia camphorata extracts. Cancer Lett 243: 109-119, 2006.

16. Hsu YL, Kuo YC, Kuo PL, Ng LT, Kuo YH and Lin CC: Apoptotic effects of extract from Antrodia camphorata fruiting bodies in human hepatocellular carcinoma cell lines. Cancer Lett 221: 77-89, 2005 .

17. Hsieh YC, Rao YK, Wu CC, Huang CY, Geethangili M, Hsu SL and Tzeng YM: Methyl antcinate A from Antrodia camphorata induces apoptosis in human liver cancer cells through oxidant-mediated cofilin- and Bax-triggered mitochondrial pathway. Chem Res Toxicol 23: 1256-1267, 2010

18. Lu YF, Chen GM, Zhong LY, et al: The safety evaluation of ethanol extract of Antrodia camphorate. J Toxicol 29: 388-390, 2015 (In Chinese).

19. Livak KJ and Schmittgen TD: Analysis of relative gene expression data using real-time quantitative PCR and the 2(-Delta Delta C(T)) method. Methods 25: 402-408, 2001.

20. Yang HL, Hseu YC, Chen JY, Yech YJ, Lu FJ, Wang HH, Lin PS and Wang BC: Antrodia camphorata in submerged culture protects low density lipoproteins against oxidative modification. Am J Chin Med 34: 217-231, 2006.
21. Mizuno $\mathrm{M}$, Morimoto $\mathrm{M}$, Minato $\mathrm{K}$ and Tsuchida $\mathrm{H}$ Polysaccharides from Agaricus blazei stimulate lymphocyte T-cell subsets in mice. Biosci Biotechnol Biochem 62: 434-437, 1998.

22. Huang $\mathrm{CH}$, Chang CC, Lin CM, Wang ST, Wu MT, Li EI, Chang HC and Lin CC: Promoting effect of Antrodia camphorata as an immunomodulating adjuvant on the antitumor efficacy of HER-2/neu DNA vaccine. Cancer Immunol Immunother 59: $1259-1272,2010$

23. Tandon M, Salamoun JM, Carder EJ, Farber E, Xu S, Deng F, Tang H, Wipf P and Wang QJ: SD-208, a novel protein kinase D inhibitor, blocks prostate cancer cell proliferation and tumor growth in vivo by inducing $\mathrm{G} 2 / \mathrm{M}$ cell cycle arrest. PLoS One 10: e0119346, 2015.

24. Lee HG, Lee JM, Shin SJ, Kwon SH, Lee GS, Song CH, Choi ES, Cha SD and Cho CH: Salinomycin inhibited cell proliferation and induced apoptosis in human uterine leiomyoma cells. Obstet Gynecol Sci 57: 501-506, 2014.

25. Hou J, Wang D, Zhang R and Wang H: Experimental therapy of hepatoma with artemisinin and its derivatives: In vitro and in vivo activity, chemosensitization, and mechanisms of action. Clin Cancer Res 14: 5519-5530, 2008.

26. Liao K, Li J and Wang Z: Dihydroartemisinin inhibits cell proliferation via AKT/GSK3 $/$ cyclinD1 pathway and induces apoptosis in A549 lung cancer cells. Int J Clin Exp Pathol 7: 8684-8691, 2014

27. Ji AJ, Liu SL, Ju WZ and Huang XE: Anti-proliferation effects and molecular mechanisms of action of tetramethypyrazine on human SGC-7901 gastric carcinoma cells. Asian Pac J Cancer Prev 15: 3581-3586, 2014.

28. Kastan MB and Bartek J: Cell-cycle checkpoints and cancer. Nature 432: 316-323, 2004.

29. Malumbres M and Barbacid M: Cell cycle, CDKs and cancer: A changing paradigm. Nat Rev Cancer 9: 153-166, 2009.

30. Dang CV, O'Donnell KA, Zeller KI, Nguyen T, Osthus RC and Li F: The c-Myc target gene network. Semin Cancer Biol 16: 253-264, 2006.

31. Podar K and Anderson KC: A therapeutic role for targeting c-Myc/Hif-1-dependent signaling pathways. Cell Cycle 9: 1722-1728, 2010.

32. Hatok $\mathrm{J}$ and Racay P: Bcl-2 family proteins: Master regulators of cell survival. Biomol Concepts 7: 259-270, 2016.

33. Green DR and Reed JC: Mitochondria and apoptosis. Science 281: 1309-1312, 1998

34. Adams JM and Cory S: The Bcl-2 protein family: Arbiters of cell survival. Science 281: 1322-1326, 1998.

35. Rao L and White E: Bcl-2 and the ICE family of apoptotic regulators: Making a connection. Curr Opin Genet Dev 7: 52-58, 1997. 